\title{
The effects of COVID-19 on the labour market
}

\author{
Beáta Kádár ${ }^{1 *}$ \\ Szeréna Nagy ${ }^{2}$, \\ ${ }^{1}$ Sapientia Hungarian University of Transylvania, Department of Business Sciences, Miercurea Ciuc, Piata \\ Libertatii 1, 530104, Romania \\ ${ }^{2}$ University of Debrecen, Faculty of Economics, \\ Károly Ihrig Doctoral School of Management and Business, Debrecen, 138 str. Böszörményi., 4032, Hungary
}

\begin{abstract}
COVID-19 is currently a pandemic of such a magnitude that it affects economy, labour market, society and all aspects of life. Many researchers are currently engaged in examining the issues, challenges and impacts caused by COVID-19. It causes changes of such nature and degree in the economy and labour market that have been unprecedented. In fact, as a result of the pandemic, the operation and composition of the economy and the structure of the labour market will change. The present study examines how Romanian respondents see the impact of COVID19 on the labour market, employment and on the different sectors of the economy.
\end{abstract}

Keywords: COVID-19, economic crisis, job market

JEL Classification: J01, J4, E24

(C) 2020 Published by ACTA MARISIENSIS, SERIA OECONOMICA, Publisher University Press Târgu Mureș, issued on behalf of University of Medicine, Pharmacy, Sciences and Technology "George Emil Palade" from Târgu Mureș, Romania

\footnotetext{
* Corresponding author: Beáta Kádár

e-mail: kadarbeata@uni.sapientia.ro
} 


\section{INTRODUCTION}

There have been various epidemics in the history of mankind, the Black Death of 1347-1352 caused the deaths of more than 75 million people worldwide, which obviously influenced the decrease of active workers and also contributed to the decrease of wages and average income. The Spanish flu, between 1918 and 1920, claimed the lives of nearly 100 million people and caused a weakening and decline in economic performance, the consequences of which also affected the performance of the economy in the 1980s. Similarly to the aforementioned epidemics, in the case of COVID-19 as well, it can be said that epidemics of this size will continue to affect the performance of the economy and the development of the labour market (worldbank.org). In recent years, several countries have suffered significant economic and public health losses as a result of various epidemics, such as the 2003 SARS (Severe Acute Respiratory Syndromes), H7N9 (Influenza A Virus Subtype H7N9), although none have had such a global impact as COVID-19 (McKibbin, Fernando, 2020b).

As a result of the global epidemic a shift in power can be expected in the economy, on the labour market, as well as all other aspects of life. The COVID-19 virus has forced society to face health, economic and social crisis at the same time. From a macroeconomic point of view, some important trends point to the decline of economic performance, rising unemployment and further reflection on these issues include the question of how developed and developing countries can address these issues to mitigate their effect (McKibbin, Fernando, 2020). As far as the labour market is concerned, the emergence of industry 4.0 has brought about new concepts and perspectives for those in search for a job and employers alike. Digitization, data and information processing have brought a whole new arena for employees, employers and economic actors as well. According to Nagy (2019) conscious and effective use of such technologies requires the development of a networked culture, as well as re-thinking values and operations of the network members (government, universities, companies). Industry 4.0 will eliminate or transform low to mid-level jobs that can be easily and completely automated.

According to a 2016 analysis by the World Economic Forum, 9\% of U.S. jobs can be fully replaced by automation, while industrial robots and machine learning threaten $47 \%$ of jobs (Schwab, 2016). At the same time, lower value-added activities and workers will be replaced by automation, but in fact the demand for workforce will increase. The only difference will be in the skills required, such as digital and computer skills (Nagy, 2019).

Industry 4.0 and the effects of COVID-19 will significantly change the structure of the labour market, both on the demand and offer side, and it will also require a more skilful workforce. Thus, one of the consequences of COVID-19 was that many employees temporarily lost their jobs, and in the case of industry 4.0, there is a certain fear among employees that digital solutions and robots will take their jobs (Nagy, 2019). From a macroeconomic point of view, Industry 4.0 and COVID19 contribute to the increase in unemployment and the increase in social and income inequalities.

\section{THE EFFECTS OF COVID-19 ON THE ECONOMY AND LABOUR MARKET}

Nowadays a central topic for researchers is the effects of COVID-19 on the economy, labour market, healthcare system, lifestyle and the population in general. We can expect significant 
changes in both the short and long term. After the COVID-19, it was clear that health, education, tourism, hospitality and other service sectors found themselves in a new situation which they were not prepared for. Some of the direct effects of the crisis include an increase in the unemployment rate, lower average incomes, which also contribute greatly to the impoverishment of society, the decline in social welfare and the increase in social inequalities. An increase in the unemployment rate, or in other words, a decrease in the ratio of human capital in terms of the production function, leads to a decrease in production and economic performance. According to the theory of human capital, education increases cognitive abilities and thus improves labour market efficiency in terms of productivity and income. It is said that skilled workers are more capable of coping with challenges caused by economic crises and are able to adapt more easily to the changing needs of employers, the environment and new technologies (blogs.worldbank.org). The direct consequences of the epidemic can be identified in the labour market, as most companies operating in different economic sectors have faced near-bankruptcy or have been forced to reduce staff.

The economic crisis caused by COVID-19 is partly different from previous crises in that it has had an immediate impact on the labour market. Several studies have examined structural changes in the labour market, such as how the ratio of people receiving education has changed compared to previous years. During the crisis period, it could be observed that income inequalities between higher-skilled and lower-skilled workers have intensified. The income of the lowerskilled labour force is declining and the unemployment rate is on the rise.

If the income of workers with higher education stays the same or decreases slightly, then the number of people enrolled in higher education will increase during the crisis. Another very interesting perspective is the impact of the crisis on different economic sectors and on the income of workers within those sectors. It can be said that agricultural workers are less exposed to and almost immune to the negative effects of the crisis. We can observe this tendency in countries with similar size farmlands. Since these countries produce more than they consume, they are not dependent on food imports and we can also observe a migration of the workforce from other sectors into the agricultural sector. Employees without any higher education are much more exposed to the negative effects of the crisis than those with higher education which also leads to income inequality. Certain strata of the workforce, especially youth without higher education and women are considered to be the most vulnerable group affected by COVID-19 (blogs.worldbank.org).

The effects of the economic crisis have been felt with a slight delay on the labour market, but COVID-19 had an immediate impact on the labour market, both on the demand and supply sides.

The International Labour Organization (ILO) is continuously analysing the economic damage caused by the pandemic on labour market. This report concludes that in the second quarter of 2020 working hours declined by $6.7 \%$ on a global level, which means the loss of a roughly 195 million full-time jobs (Csizmadia, Illéssy 2020). At the same time, in the second half of 2020 global working hours are expected to further decline which could mean the loss of 305 million full-time jobs. Furthermore, $38 \%$ of workers ( 1.25 billion workers) could become unemployed.

If we look at the economic actors, we can see that small and medium sized businesses are in the most danger. The ILO analysis points out that those workers who lost their jobs in the past few months have no possibility to enter the labour market as active job seekers (https://www.ilo.org/). The negative effects of COVID-19 on the labour market has been felt on 
every continent and in all countries; the projected decline of labour force is as follows: in the Arab states (8.1\%), in Europe (7.8\%), in Asia and the Pacific region (7.2\%) (https://www.ilo.org/).

In terms of economic sectors, the most vulnerable sectors are the hospitality industry, as well as manufacturing, retail, business and administrative activities, while about $38 \%$ of the total global workforce is employed in one of the aforementioned vulnerable sectors (Csizmadia, Illéssy 2020). The ILO estimates that unemployment could exceed 25 million by the end of the year, so four out of five people $(81 \%)$ are already affected by the partial or total closure of their employing companies (https://www.ilo.org/). At the same time, the virus has enabled a more flexible environment for employees with the introduction of the home office, even in organizations where it has not been part of the company culture so far (Csizmadia, Illéssy 2020). Based on the data published by The Central Office of Statistics Hungary (KSH) in the first quarter of 2018 only 144000 employees were working from home (3.7\% of national employees), the average of the European Union was 5\% and in certain countries, like Holland and Finland, the ratio of homeworkers is above $10 \%$ compared to the total workforce(http://www.regscience.hu/).

The labour market is undergoing a transformation, one of the antecedents of which is the effects of COVID-19 and the emergence of industry 4.0 as another important factor. At the same time, one of the consequences of this labour market transformation will be the transformation of higher education. Future graduates must have the knowledge, skills and mentality with which they can enter the labour market and meet the challenges of the future; they will need practical knowledge but several skills and abilities as well (Gebei, Vincze 2020).

\section{THE COVID-19 PANDEMIC EFFECTS IN ROMANIA AND OTHER COUNTRIES}

One of the key questions of today's world is: What trends and tendencies will emerge in the labour market? Prior to the pandemic crisis, there was already a workforce shortage in the Romanian labour market. This situation was made worse by the coronavirus pandemic, which led to further unemployment and job shortages.

COVID-19 has led to significant changes in all countries. In Japan, by the end of February, most companies had already implemented home office system. On March 3, Ford Motor Company banned workers from traveling abroad. According to Zhengsheng Zhong, a financial expert at CEBM Group, said both demand and supply weakened and supply chains stagnated. In East Asia, production fell abruptly, especially in Australia, South Korea, Japan, Vietnam and Taiwan. In order to protect employment, the German government developed a state-funded program called "Kurzarbeit" as a response to the global crisis. China, Hong Kong and Singapore have made decisions, and implemented various financial policies to maintain economic stability (Baldwin, 2020). In the last two years, the unemployment rate in Romania has not been as high as since the COVID-19, namely 3.9\% in February and 4.6\% in March. In the period 2008-2009, 22 million jobs were lost globally, and by the second half of 2020, this proportion will reach 195 million. In Romania, more than 725,000 employment contracts had been terminated by 30 April 2020, with the largest share in manufacturing $(181,000)$, followed by trade and tourism (https://www.zf.ro/). The analysis called The coronavirus in Transylvania shows that barely $63 \%$ of those working in February still had their jobs at the beginning of April, and 4 out of 10 people may be in a socially vulnerable situation. The report also shows that the effects of the pandemic have had a drastic impact on the labour market. Many employees who had a job in February stated that due to the epidemic they immediately lost their jobs $-22 \%$ were forced to take their annual leave, while $5 \%$ 
were on unpaid leave. Those who thought their jobs to be safe did mostly intellectual work, and a significant number of them worked in the public sector and the basic services sector, as well as in the communications and IT sectors. In terms of economic sectors, those working in agriculture were less exposed to the negative effects of the virus. Working conditions are also constantly changing, with one-fifth of those surveyed doing work exclusively from home, while $8 \%$ do their jobs from home and partly from home (erdelystat.ro).

According to a research conducted by Profession.hu on a representative sample of Hungarian workers, nine out of ten companies are affected by the pandemic crisis. Over the next six months, $50 \%$ of workers expect the situation to get worse, $30 \%$ say it will not change, while $10 \%$ are uncertain about the situation. $40 \%$ of employees surveyed said their company's position will improve over the next six months (profession.hu). In Hungary, more than half of the employees $(59.2 \%)$ work in high- and medium-risk sectors. It is also important to interpret this ratio from the perspective of the national economy. The contribution of sectors to GDP is very high, so it also means a decrease in GDP and an increase in the unemployment rate and a decrease in purchasing power and demand due to loss of income.

\section{RESEARCH METHODS}

The present study consists of two major parts. In the first part the theoretical background and the secondary research results are presented, while the second part reports on the results of the primary research. The secondary research or desk research involved the use of existing statistical reports, national and international publications and research results in order to get an insight into the effects of COVID-19 on the labour market. The second part of the paper presents the data and results of our survey questionnaire.

Data was collected in April and May 2020 using an online questionnaire. The questionnaire involved participants aged between 18 and 30, mostly university students. Regarding the structure of the questionnaire, the first part contained questions about the effects of the virus on the economic and labour market. The questions in the second part focused on the future perspectives of the aforementioned issue, and the demographic data in the third part.

Data was analysed using Excel and SPSS software. We created the diagrams using the Excel program and the descriptive and comparative statistics using the SPSS program. Crosstabulation analysis was used to examine the existence of a relationship between variables and the closeness of the relationship.

\section{RESEARCH RESULTS}

The present section of the paper presents the results of the research starting with the description of the sample, analysing the demographic data gathered through the questionnaire. From the responses provided it can be stated that $54 \%$ of the research participants were female, 
while $46 \%$ were male. In terms of participants' place of residence, results show that $43 \%$ live in cities, $33 \%$ in villages, while $24 \%$ live in county seats. Figure 1 below presents theeducational background of the respondents, namely that $62 \%$ have a university or college degree, while $38 \%$ graduated from high school.

\section{Figure 1 - Percentage of respondents by education}

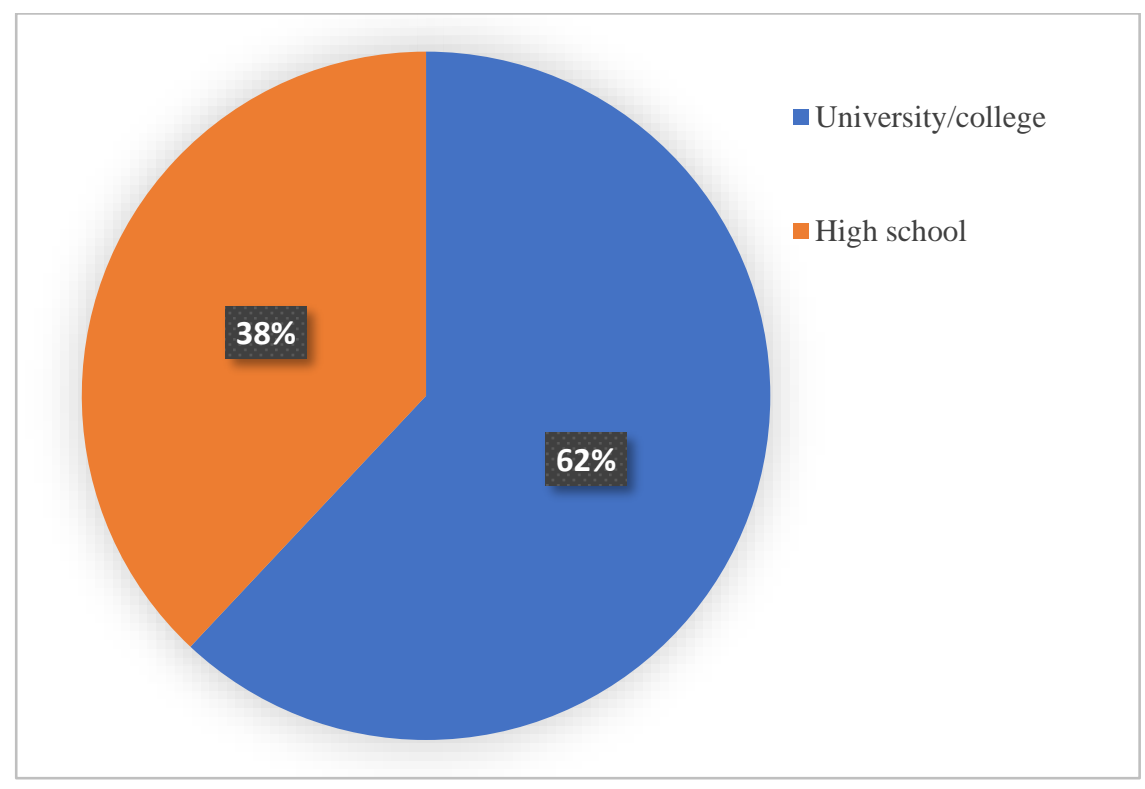

Source: Authors'own elaboration

The majority of the above-mentioned group of respondents having university or college degree attended university as full-time students. Those who are currently studying at a university are going to enter the labour market in short period of time therefore, will be highly influenced by the economic crisis caused by the pandemic. $27 \%$ of the respondents are currently employed, $59 \%$ are not employed, $9.5 \%$ have a part-time job, $2.4 \%$ do remote work to sustain their living, and $1.9 \%$ have taken part in an internship during the time of data collection.

For what concerns the respondents' academic specialization, participants were asked to choose the academic specialization there are currently majoring in or the field in which they have obtained their degree.

Figure 2 below shows that the majority of the respondents are majoring in or have a degree in social sciences and economic sciences (32\%), 5\% are in the field of business sciences. Therefore, it can be said that most of the respondents have some experience or knowledge in economy. At the same time, $19 \%$ of the participants are learning or obtained a degree in IT or technical sciences. The fields of healthcare, education, veterinary sciences, communication and public relations are poorly represented, while there were no respondents from the field of hospitality or tourism.

University students who are currently studying are going to enter the labour market soon in such a way that COVID-19 has brought about different learning conditions and environment for them. On the other hand, those who have already been employed are able to compare life and work prior to COVID-19 and the way things have changed after the pandemic. One of the questions in the questionnaire aimed to find out participants' opinions and beliefs regarding the effects of the pandemic on their field of study or work. 
Figure 2 - Academic specialization

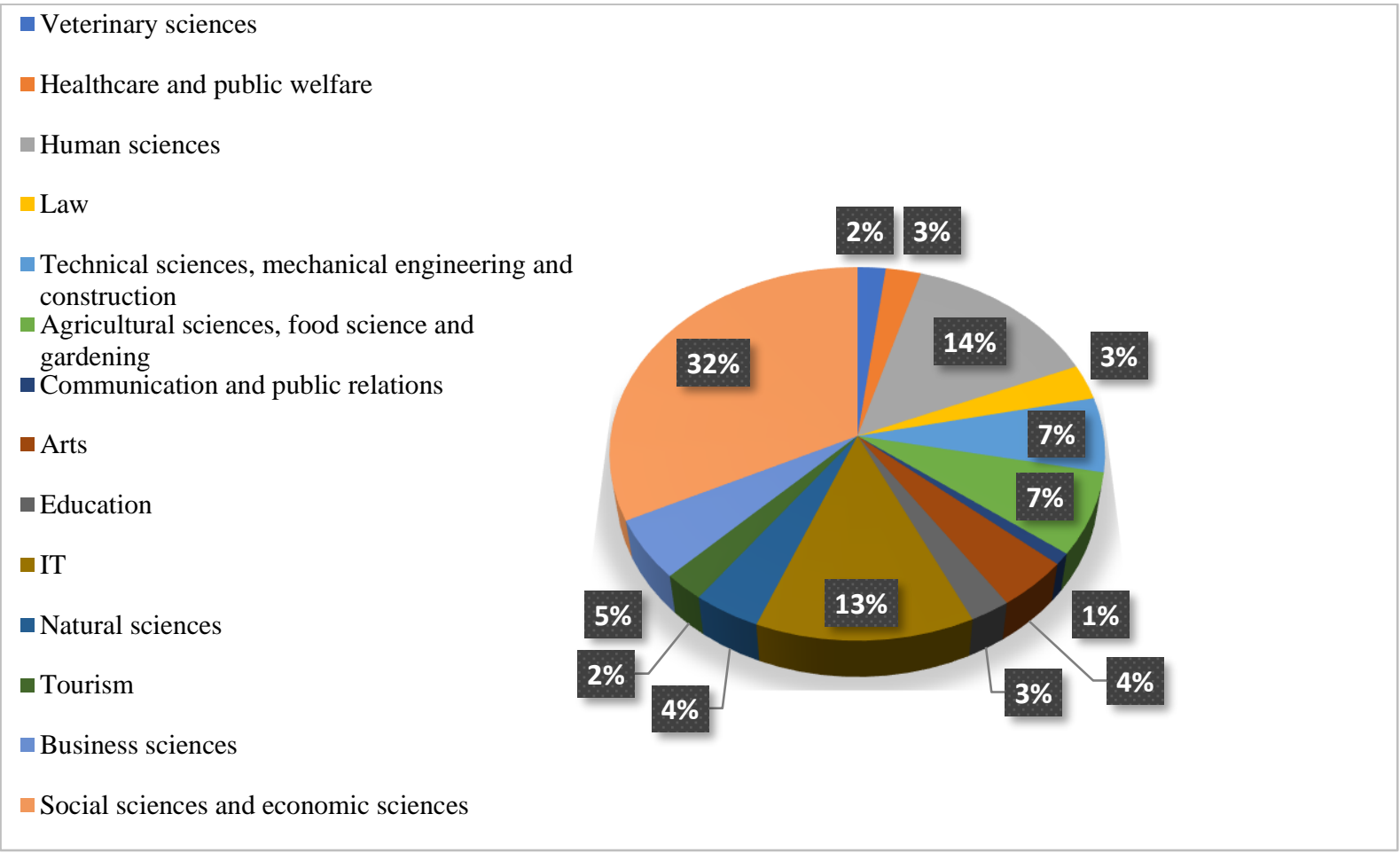

Source: Authors' own elaboration

Answers had to be given on a 7-point scale, between -3 and +3 depending on whether they expected positive or negative effects of the pandemic. $62 \%$ of the respondents believe that the COVID-19 will have negative impacts on their field of study or work, while $23 \%$ believe in positive effects and yet another $15 \%$ think that the pandemic will have no effects whatsoever on their field of study or work. A following question tried to further expand this idea and asked participants to express their opinions regarding the extent to which COVID-19 will influence the labour market and how will jobs in the given fields of study or work be impacted.

According to Figure 3 above participants believe that the pandemic will have strong negative effects on the labour market, irrespectively to the given fields. The greatest negative impact was thought to be felt in the fields of social sciences and economics, human sciences, IT and arts, followed by tourism and business sciences. Thus, it can be concluded that respondents agree that the pandemic will have a negative impact on the labour market in general. However, what seems to be interesting, is that the IT sector is also thought to be negatively affected by the pandemic, in spite of the fact that since COVID-19 hit IT became important in virtually every field, and IT has a major role to play together with the emergence of industry 4.0 and the rising demand for workers with IT skills. If we look at the demographic differences $38,9 \%$ of men and $61,1 \%$ of women believe that the pandemic has had a negative effect on the aforementioned sectors. Women especially predict greater negative effects compared to men in all fields and also the overall 
Beáta KÁDÁR, Szeréna NAGY

economy. $57,1 \%$ of women believe that the pandemic will have a significant negative impact on the given country's economy while in the case of men the ratio is $42 \%$.

\section{Figure 3 - The positive and negative effects of the pandemic on the labour market by academic specialization}

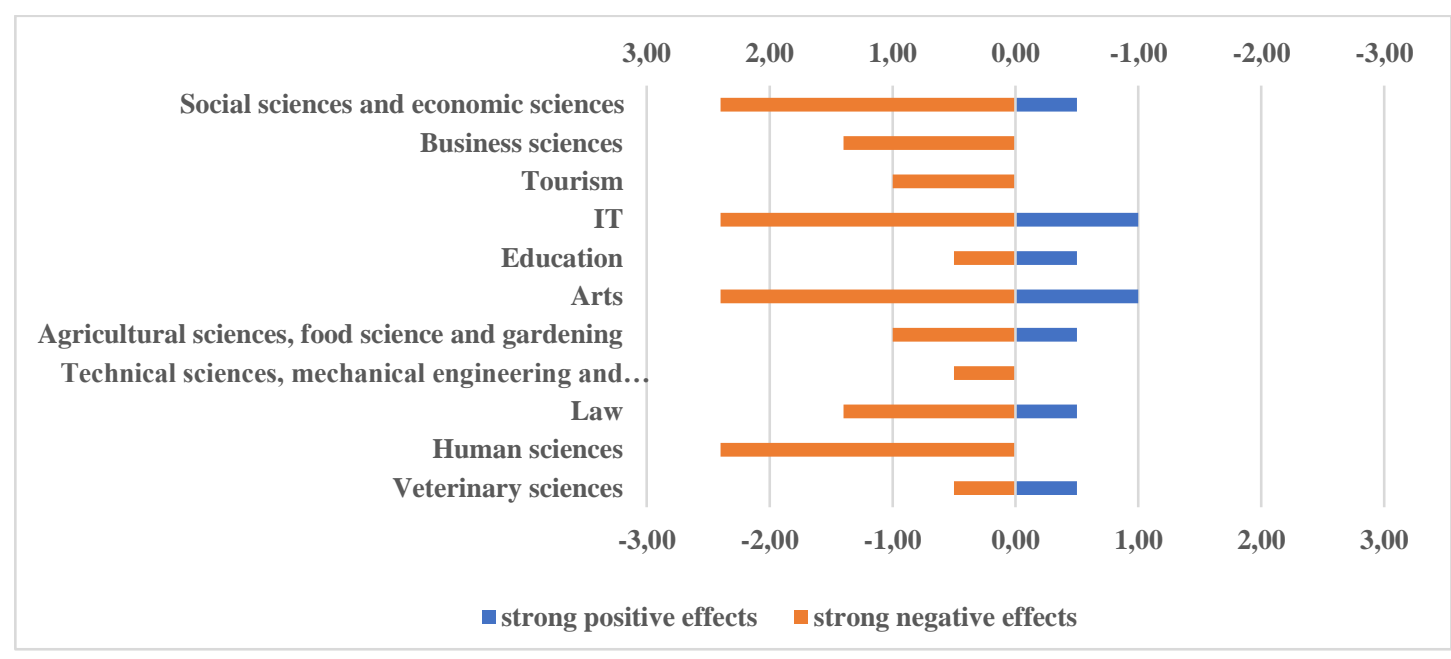

Source: Authors' own elaboration

A few questions from our questionnaire aimed to explore the opinion about working abroad and how it will be impacted by COVID-19 both on the demand and supply side of the labour market. $86 \%$ of respondents believe that it will be possible to find work abroad in their respective field and $14 \%$ believe there won't be opportunities abroad. The subject of working abroad revealed an interesting split of 50-50 between those who considered looking for work abroad and those who would rather not. $26,7 \%$ of men and $23,3 \%$ of women considered looking for work abroad and $19,5 \%$ of men and $30,5 \%$ of women would not seek employment abroad.

\section{Figure 4 - Work abroad}

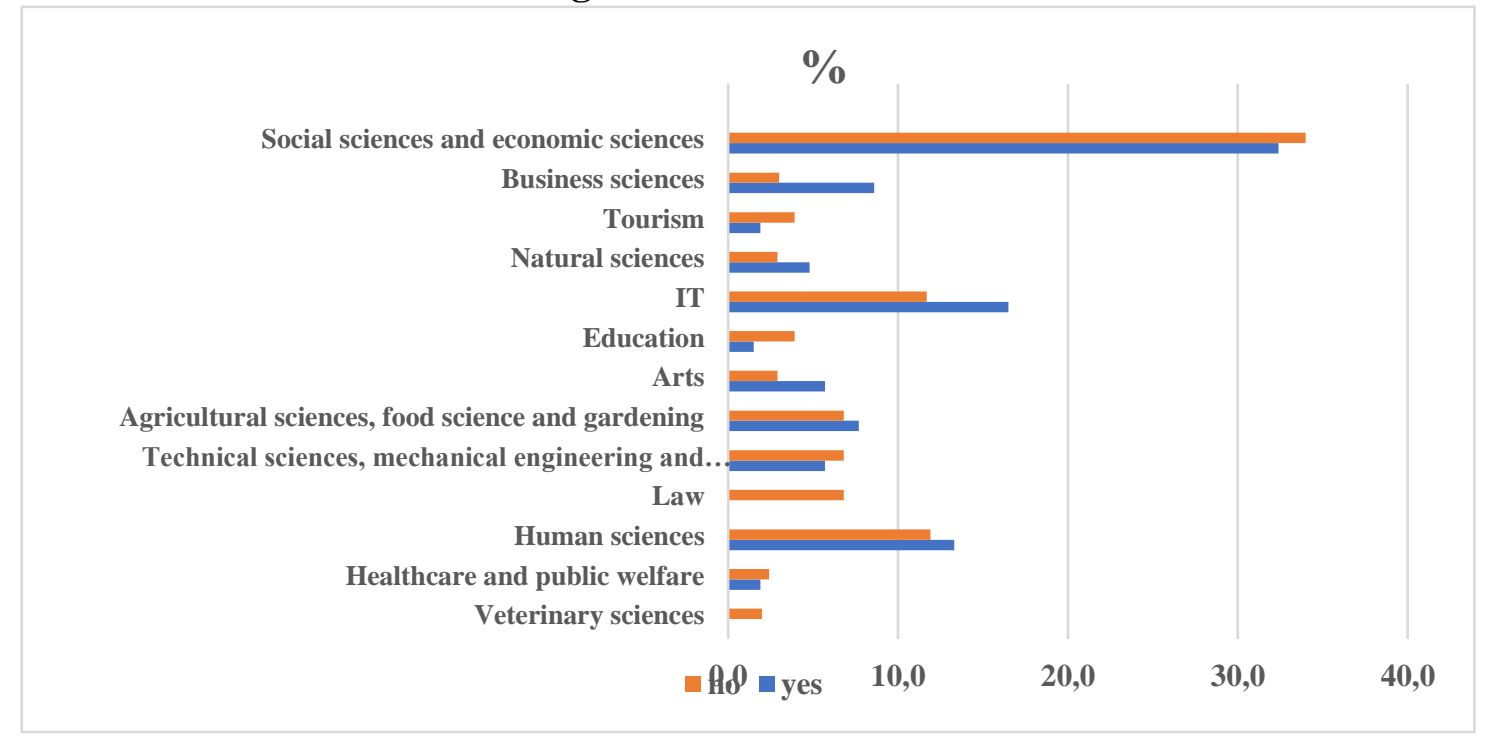

Source: Authors' own elaboration 
Crosstabulation analysis was used to examine the relationship between the field of work and working abroad, which can partly predict workforce migration and the evolution of the domestic labour market. There are several reasons for the migrations of the workforce but the most defining is the appeal of a higher income. COVID-19 will greatly impact the economic performance of countries and one of the negative consequences will be a decrease of the average income in developing countries, which in turn will lead to an increase in the workforce migration to countries and sectors with a higher earning potential.

Figure 4 illustrates the respondents' stance on working abroad. Those with studies in humanities and economic sciences would work abroad with a ratio of $32.4 \%$, closely followed by IT $16.5 \%$, business studies $(8.6 \%)$ and agriculture $(7.7 \%)$. If we look at the distribution of respondents by their field of work, we can see that those who expressed a strong willingness to work abroad work in the field of IT, business, natural sciences and agriculture. It can be said that it is not hard to imagine working abroad in several fields but a few of them are chosen based on the promise of a higher earning potential.

\section{Figure 5 - Successful academic specializations after the pandemic}

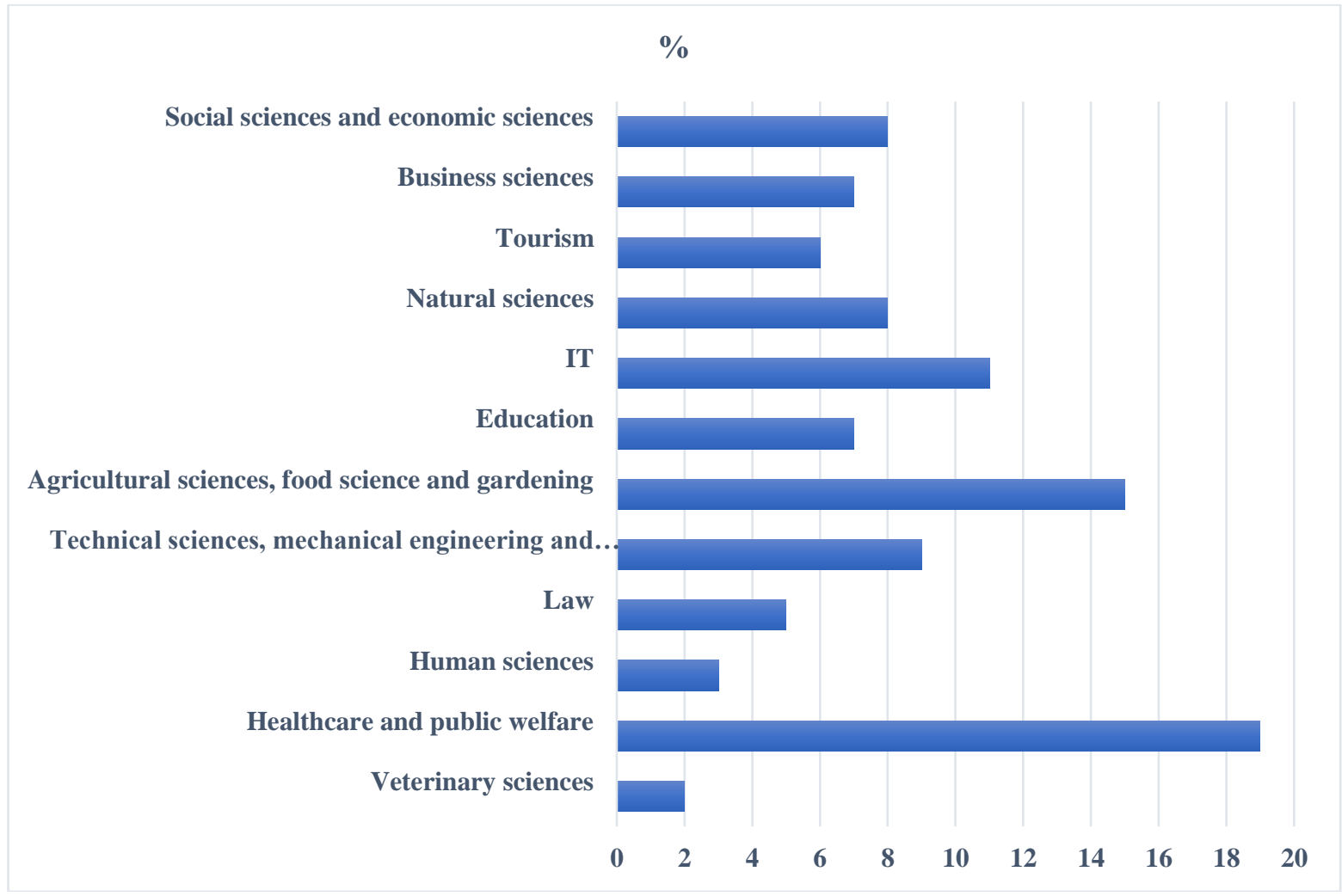

Source: Authors' own elaboration

We also need to consider the perspective of those enrolled in higher education, or recent graduate students of universities and high schools and their take on the negative effects of the pandemic, on the labour market, as well as working abroad. Those who are university students and 
recent higher education graduates (63.3\%), high school graduates (36.7\%) believe that the pandemic will have significant effects on the labour market which might severely impact current and future job seekers. The above conclusion is also true as far as the economy is concerned: $40 \%$ of high school graduates and $60 \%$ of university students/recent graduates believe that the pandemic will hurt the overall economic performance. On the long term, the current generation of students will have to face the most difficult situation on the labour market since the significant changes and they will also have to face a worse economic situation.

The global pandemic has caused significant shifts on the labour market both on the demands and supply side. When examining the demand side of the labour market we set out to explore respondents' predictions about the kind of fields/sectors that they think will be successful in the next 2-5 years following the pandemic. 19\% of respondents believe that public health and healthcare in general will grow in the years after the pandemic. The fields which will also experience growth are: agriculture, horticulture, food processing $15 \%$ and IT with a ratio of $11 \%$.

\section{CONCLUSIONS}

We can conclude that after examining the relevant literature and analysing our questionnaire data the COVID-19 pandemic caused structural changes in the global economy giving rise to new trends and having a significant impact on the labour market. During the pandemic the importance of healthcare has risen, this might be why respondents believe that this field will experience significant growth. More people will seek employment in the agricultural field and agriculture will become more important than ever in the years after the pandemic has passed. The population of the planet is on the rise and agricultural output and production needs to keep up, in the next 40 years we need to increase food production by $60 \%$ to meet global demand (http://www.fao.org). As far as IT is concerned the pandemic forced more and more people to work from home. The emergence of industry 4.0, the concept of home office, storing and processing data are crucial to thrive in a competitive and innovative economic environment. The majority of respondents are pessimistic about employment opportunities with the exception of a few key fields (agriculture, healthcare, IT) where demand for human capital will grow. The future generation of workers who are still students at the moment will be greatly affected by the negative effects of the pandemic and they are aware of this fact. These students about to enter the workforce will face a completely different landscape on the labour market.

\section{Bibliography:}

Csizmadia P. - Illéssy M. (2020) : A nagy leállás, a magyar munkahelyek közel fele került veszélybe [Marea oprire, aproape jumătate din locurile de muncă din Ungaria este în pericol]; https://www.socio.mta.hu/, letöltés: 2020. 06.17.

Nagy J. (2019): Az ipar 4.0 fogalma és kritikus kérdései - vállalati interjúk alapján[Conceptul de industrie 4.0 și întrebări critice legate de acesta - bazat pe interviuri], L . ÉVF. 2019. 1. SZÁM/ ISSN 0133- 0179 DOI: 10.14267/ VEZTUD.2019.01.02

Richard B.-Beatrice W. M. (2020): Thinking ahead about the trade impact of COVID-19 In: Richard Baldwin and Beatrice Weder di Mauro (eds.), Economics in the Time of COVID-19, CEPR Press, p. 59-72, ISBN: 978-1-912179-28-2

Schwab, K. (2016): Fourth industrial revolution: what it means, how to respond. World Economic Forum, p. 1-8. 
Gebei T- Vincze Sz. (2020): Felsőoktatási továbbtanulási preferenciák összehasonlítása a munkaerőpiac igényeivel[Comparația preferințelor de studii superioare cu cererile de pe piața de muncă], International Journal of Engineering and Management Sciences (IJEMS) Vol. 5. (2020). No. 1 DOI: 10.21791/IJEMS.2020.1.32

Warwick M.-Roshen F. (2020a): The economic impact of COVID-19, In: Richard Baldwin and Beatrice Weder di Mauro (eds.), Economics in the Time of COVID-19, CEPR Press, p. 45-52, ISBN: 978-1-912179-28-2

http://europass.hu/az-ilo-kozzetette-legujabb-beszamolojat-a-covid-19-koronavirus-jarvanymunkaeropiaci-hatasairol

http://regscience.hu:8080/jspui/bitstream/11155/2203/1/lennert-sars-2020.pdf http://regscience.hu:8080/jspui/bitstream/11155/2210/1/Lennert-tavmunka-2020.pdf http://www.fao.org/fileadmin/templates/wsfs/docs/Issues_papers/HLEF2050_Global_Agriculture. pdf, accesat: 2020. 06.17.

http://www.regscience.hu:8080/xmlui/handle/11155/2210, accesat: 2020. 06. 22

https://blogs.worldbank.org/education/impact-covid-19-labor-market-outcomes-lessons-pasteconomic-crises, accesat: 2020. 06.17.

https://blogs.worldbank.org/education/impact-covid-19-labor-market-outcomes-lessons-pasteconomic-crises

https://szociologia.tk.mta.hu/uploads/files/Csizmadia-Illessy_A_virus_es_a_munka-F.pdf https://voxeu.org/article/covid-19-lockdown-and-eu-labour-markets

https://www.bis.org/publ/bisbull07.pdf

https://www.profession.hu/blog/a-dolgozok-fele-biztos-benne-hogy-nem-lesznek-elbocsatasok-amunkahelyen/, accesat: 2020.06. 22

https://www.zf.ro/eveniment/pandemia-a-trimis-in-somaj-cel-mai-mare-numar-de-angajati-din19112772, accesat: 2020. 06. 22 